„Przekłady Literatur Słowiańskich”. T. 10, cz. 1

ISSN 2353-9763 (wersja elektroniczna)

DOI https://doi.org/10.31261/PLS.2020.10.01.09

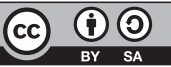

\title{
Periphery within One Language: \\ Challenges of Dialect Fairy Tales Translation into Standard Slovak
}

\author{
Periféria v rámci jedného jazyka \\ Výzvy prekladu nárečových rozprávok \\ do spisovnej slovenčiny
}

\author{
Miroslava Gavurová \\ iD https://orcid.org/0000-0002-3965-7769 \\ UNIVERSITY OF PREŠOV \\ mgskola@gmail.com
}

Date of application: 15.05.2019 ～Date of acceptance: 29.09.2019

\begin{abstract}
The present study focuses on the challenges of the intralingual translation from the peripheral dialect into official, standard Slovak that has been performed on unique Šariš region dialect fairy tales preserved in the village Fintice. They have been published recently in a bilingual form with their Slovak translation Zazračni dzvonček Zázračnýzvonček (FACE 2018). The first part of the paper points out the peripheral aspects of the analysed text and stresses the importance of presenting such forgotten literary pieces for the community identity as well as for preserving community cultural heritage. The second part of the paper focuses on translation analysis and differences between the two texts on morpho-syntactic and lexical level, and in the degree of expressiveness.
\end{abstract}

KEYWORDS | Intralingual translation, dialect, fairy tales, periphery, community identity, community cultural heritage 


\section{Introduction: The Subject of the Analysis}

Slovak fairy tales are considered to be a part of our folk tradition as well as of our national literature, and therefore they are believed to be the golden treasure of our national culture. ${ }^{1}$ Accordingly, dialect fairy tales preserved once in a spoken tradition and only much later transcribed into their written form might be perceived likewise, their form being a territorial variety of a national language. The reason why fairy tales tales were preserved in oral tradition lies in "their moral strength, their indomitable belief in the victory of good, justice and honour" that are reflected as their fundamental moral and compositional principle. $^{2}$

In our paper, we concentrate on Šariš dialect fairy tales from Fintice in eastern Slovakia and the specifics of their intralingual translation to standard Slovak. The stories were collected by Jozef Kolarčík-Fintický (1899-1961) who - among many other activities and professions - was a teacher, organist, ethnographer in Fintice and managed to record hundreds of unique cultural artefacts from Fintice and elsewhere in eastern Slovakia. The intriguing fact about the presented fairy tales is that a few older inhabitants of the village do remember their parents and grandparents telling them some of the stories in their childhood. That allows us to assume the stories were once kept and transferred in a spoken tradition and later (the 1940s and 1950s) transcribed by Jozef Kolarćík. This is also the justification of the assumption that the fairy tales are part of the cultural heritage of Fintice community (see here the chapter "Community Identity, Cultural Heritage, Cultural Resilience"), alongside, for example, its typical folk dance (called Do šaflika) or folk songs with lyrics referring to the Fintice area.

The fairy tales were first published in a thin volume Zazračni dzvonček Starodavne rosprafki s Fincic (Miraculous Little Bell - Old-time Fairy Tales from Fintice; FACE, 2015). ${ }^{3}$ From the number of shorts stories, tales and legends preserved in the Kolarčík's estate the following five authentic stories for children were selected:

- Jak bul vilk u Satkovich na veśelu [How a Wolf Went for a Wedding at the Sadkos];

- Zazračna dupa - kohucik vislužil, kurka ňe [Magic Bum - The Wolf Earned, a Hen Did Not];

1 J. Kačala, 1989: Slovenské ludové rozprávky a ich súčasné úpravy. „Kultúra slova”, vol. 23, no. 4 , p. 98.

2 J. Kačala, 1989: Slovenské ludové rozprávky..., p. 99.

3 J. Kolarčík, 2015: Zazračni dzvonček - Starodavne rosprafki s Fincic. Ed. M. Gavurová. Fintice, FACE. 
- Sprosti vilk [Stupid Wolf];

- Chto mudri - ňeglupi [Who is Clever is Not Stupid];

- Zazračni dzvonček [Miraculous Little Bell].

Three years after the first dialect-only edition, a Šariš-Slovak version was published with the Slovak translation of the original Šariš stories. ${ }^{4}$ One might ask if it is not actually counter-productive in terms of the preservation of the peripheral form to translate the peripheral dialect to standard form of the national language and publish them alongside. This is a legitimate question but there was a deliberate reasoning behind the project of intralingual translation.

The idea of publishing folk tales as such lies in the shared belief that they "preserve the linguistic legacy of the previous generations, they confirm our language and national continuity." As a nation we are morally obliged to make sure that this continuity lasts and is further developed. ${ }^{6}$ If this is true of the fairy tales in standard Slovak language, it is just as applicable to the folk narratives in a dialect because they preserve the unique linguistic and cultural identity of a specific, regionally bound language community.

One significant means of preserving this continuity of tradition is - according to Ján Kačala - mediating the fairy tales to the youngest generation in such a form and by such means that they can understand them in a complex way on both an ideological and linguistic level - with those language elements that the fairy tales bring and revive in our consciousness. ${ }^{7}$

Our personal observation is that the dialects in Slovakia are moving towards the periphery of the linguistic interests of younger generation. In a bilingual edition the original Šariš stories might draw their attention to the lexical richness of the dialect, its morpho-syntactic specifics and complexity, to its unique reflection of reality. On the other hand, their Slovak version published alongside ensures they have complex understanding of the text. The overall goal of such a project is to encourage parents to speak to their children in a dialect, to understand the command of a dialect as an advantage for a child in developing his cognitive abilities and linguistic competence - rather than a disadvantage and hindrance.

The reasoning is in accordance with the Casanova's view that we share: "It is possible to measure the literariness (the power, prestige, the volume of linguistico-literary capital) of a language, not by the number of writers and readers in this language, but by the number of literary polyglots (or main players

4 J. Kolarčík, 2018: Zazračni dzvonček - Starodavne rosprafki s Fincic - Zázračný zvonček - Starodávne rozprávky z Fintíc. Ed. M. Gavurová. Fintice, FACE.

5 J. Kačala, 1989: Slovenské ludové rozprávky..., p. 102.

6 J. Kačala, 1989: Slovenské ludové rozprávky..., p. 102.

7 J. Kačala, 1989: Slovenské ludové rozprávky..., p. 102. 
in the literary arena, publishers, cosmopolitan intermediaries, well-educated

116 talent spotters...) who know it and by the number of literary translators - for export as well as for import - who cause texts to be translated into or out of this literary language."

We also strongly believe it is necessary to look for the instances of literary works in Šariš dialect that are worthy of publication in their original form; for 'hidden gems' that should be at the same time mediated to the wider reading audience via the standard form of the language. At the same time, many worthy pieces of literature might be translated into Šariš dialect. Both directions of interlingual translation of the dialect texts into standard Slovak and the bilingual edition should help those who do not understand Šariš dialect to revive it, to help it survive, to find and encourage its new speakers. As Michael Cronin adds: "A language may have many millions of speakers and a rich literary tradition but if it is bereft of translators or of opportunities for translation wider perceptions of its 'literariness' will suffer."

\section{Peripheral Aspects of Dialect Fairy Tales}

It is vital to point out how the concept of periphery that is discussed here concerns the subject of our analysis:

- the source text is in Šariš dialect that is peripheral to the standard form of the Slovak language;

- peripheral is also the intralingual translation from the dialect to a standard form of a language; there are not many instances of this type of translation within the Slovak literary context;

- the analysed material is a written dialect discourse that is peripheral to the prevailing spoken dialect utterance;

- ultimately, dialect fairy tales are peripheral to the mainstream fairy tales in standard Slovak.

The dialect used in Šariš fairy tales from Fintice is peripheral in relation to normative Slovak; yet its function is significant. Standard Slovak originated from the dialects which are essential for the thorough understanding of older periods of Slovak - especially those that we do not have written records of because some aspects and phenomena preserved in the dialects are the only

8 P. Casanova, 1999: La Republique mondiale des lettres, Paris, Seuil, p. 37; cf. M. Cronin, 2006: Translation and Identity. Oxford-New York, Routledge, 2006.

9 M. Cronin, 2006: Translation and Identity..., p. 123. 
evidence and illustration of Slovak language development. ${ }^{10}$ Slovak dialects have long been perceived as the "organically intertwined parts of Slovak language, in which the Slovak language development is reflected in full. It is the reference material that has great advantage: it is complete and one can consult it and verify it anytime. ${ }^{11}$

Moreover, because the folk tales depict the topics strongly associated with the older periods in the history of a particular society, and because in a written form they were recorded mostly in the last centuries, they preserve the old state in the development of the language, mainly its vocabulary and syntax. They petrify unique means of expression that are disappearing - for various reasons - from the contemporary language. ${ }^{12}$ The cognitive function of fairy tales as far as their language form is concerned cannot be overlooked. ${ }^{13}$

Even though the above statements originally refer to Slovak fairy tales, the same is applicable - maybe even to a greater extent - to dialect narratives.

It is also the setting of the fairy tales - the rural countryside depicted - that is often perceived as peripheral. But we believe that because of these attributes the fairy tales should be shifted towards the centre so they get the proper attention of the Slovak language community, because: "[i]t is important that we track the instances of translation which highlight the micro-cosmopolitan complexity of places and cultures which are often outside the critical purview of the urban metropolis." ${ }^{\prime 4}$ Though focusing on the cultural heritage of rural areas has a long and rich tradition in Slovakia, its main manifestations are usually pieces of folk music, dance and theatre activities. Very rarely are they literary works of folk character, written in authentic dialect by an anonymous author, as it is the case of the analysed text. Therefore, we should pay attention to dialect literary works and present their richness and uniqueness. As Michael Cronin adds:

Such a move, an integral part of the micro-cosmopolitan project, would both revitalize inquiry into a substantial body of the world's literature, both written and oral, which has the rural as its focus and also have important implications for the development of a progressive approach to translation theory and practice in rural communities throughout the world. ${ }^{15}$

10 F. Buffa, 1969: Polstoročie výskumu slovenských nárečí. „Slovenská reč”, vol. 34, no. 1, p. 14.

11 E. Paulíny, 1963: Fonologický vývin slovenčiny. Vydavatelstvo Slovenskej akadémie vied, p. 5.

12 J. Kačala, 1989: Slovenské ludové rozprávky..., p. 102.

13 J. Kačala, 1989: Slovenské ludové rozprávky..., p. 102.

14 M. Cronin, 2006: Translation and Identity ..., p. 18, emphasis added.

15 M. Cronin, 2006: Translation and Identity..., p. 1. 


\section{Community Identity, Cultural Heritage, Cultural Resilience}

When talking about the periphery it is necessary to mention the concept of identity, more specifically, community identity, as we believe there is a strong and multilayered connection between those two concepts.

There are several successful attempts to approach and define identity from different angles; here we adopt the cultural studies' concept that perceives identity as "a cultural construct because the sources that serve as material for forming identity are of cultural origin." ${ }^{16}$ If identity per se is of a cultural nature, this is much truer of community identity as a community very often has its own distinctive and unique culture.

Identity is inherent to communities of different sizes, of both peripheral and central locations. Yet we believe the identity of rural communities is specific in several ways; it is definitely more likely to be based on folk traditions and geographical specifics.

Rural areas that have strong place identities, formed through the reproduction of traditional cultural practices alongside contemporary influences. These identities are performed and constructed through a varied repertoire of knowledges, histories, and customs. Their on-going production can be central to community identity as they attempt to make visible their own accounts of history and place. ${ }^{17}$

Community identity is very closely related to the community cultural heritage. The analysed fairy tales represent the local cultural heritage of the village of Fintice. Publication of these fairy tales proves that "strong senses of regional expression or identity, partly cutting affiliation to nations have been found recently in a number of places." ${ }^{18}$ Presenting them to the reading audience might be perceived as a contribution to forming a cultural archive of Fintice community:

Central to the production of community heritage archives is the volunteer labour that maintains and produces the archives. It is this social and cultural activity that represents human agency and is shaping the resilience to preserve the collective memories and histories of a particular place. ${ }^{19}$

16 Ch. Barker, 2006: Slovník kulturálních studií. Praha, Portál, p. 74.

17 D. Beel et al. 2017: Cultural Resilience: The Production of Rural Community Heritage, Digital Archives and the Role of Volunteers. „Journal of Rural Studies” 54, p. 459.

18 A. Paasi, 2011: The Region, Identity, and Power. Procedia. „Social and Behavioral Studies" 14, p. 9.

19 D. Beel et al. 2017: Cultural Resilience..., p. 461. 
Publication of a book is a cultural heritage activity that reinforces not only the community identity but has an impact on several other levels too. It is a means of cultural resilience of the peripheral, rural location as "cultural practices develop resilient behaviours for rural communities." ${ }^{\text {20 }}$ It also serves as a counteraction to the threatening and negative shift from the rural towards the urban because " $t \mathrm{t}] \mathrm{he}$ accelerated drift from the countryside in most parts of the world is a factor that detracts from rather than enhances cultural diversity and represents a significant threat to linguistic diversity, to name but one component of cultural specificity." ${ }^{21}$ And linguistic diversity is perceived as a part of cultural specificity. ${ }^{22}$

Finally, when we contemplate the issues of periphery, translation and identity it is useful to bring into play Cronin's idea of micro-cosmopolitanism (see chapter "Peripheral Aspects of Dialect Fairy Tales") because it also stresses the importance of diversity: "A key element of the micro-cosmopolitan argument being advanced here is that diversity enriches a country, a people, a community" but at the same time "that diversity should not be opposed to identity by a dismissive, macro-cosmopolitan moralism." ${ }^{23}$ All in all, the previously mentioned concepts are not only intertwined but also provide a solid base for the endeavours to turn to what defines each and every community in terms of language and culture.

\section{Pitfalls of Translation within One Language}

It is a well-known fact that archetypal fairy tales once existed in a more or less variable spoken form and only later were recorded in a written form. This transfer was inevitably accompanied by necessary modifications that lead towards the stabilized form of the tales. ${ }^{24}$ When transcribing the spoken dialect version to a written form in the 1950s, Jozef Kolarćík clearly respected the narrative style of his narrators which showed strong affiliation with the oral folk tradition and which, in itself, required certain changes to be made in a written Slovak translation.

20 D. Beel et al. 2017: Cultural Resilience..., p. 460.

21 M. Abley, 2003: Spoken Here. Travels among Threatened Languages. London, Heinemann, emphasis added. Cited in: M. Cronin, 2006: Translation and Identity. OxfordNew York, Routledge, 2006.

22 M. Abley, 2003: Spoken Here..., cited in: M. Cronin, 2006: Translation and Identity. Oxford-New York, Routledge, 2006.

23 M. Cronin, 2006: Translation and Identity..., p. 18, emphasis added.

24 J. Kačala, 1989: Slovenské ludové rozprávky..., p. 101. 
But an original spoken form being transferred to a written one in dialect and later into Slovak were not the only specifics that had to be respected during the transition process. Even before the process we were aware of the pitfalls of this intralingual transfer that do not make the task easier in comparison to a (traditional) interlingual transfer. The following commentary explains the particular pitfalls of intralingual translation that we had anticipated and that actually occurred throughout the process of translation. Of course, there were many more but the following account concentrates on the shifts on a morpho-syntactic and lexical level.

\section{Morpho-syntactic Differences}

Differences on the morpho-syntactic level between the two language varieties include shifts of word-order (A), changes in prepositional phrases (B) as well as different valency of verbs (C).

(A) When examining the original word order of the dialect fairy tales, not only word-order rules but also the specifics of the oral narration have to be taken into account. As a matter of fact, the analysis of the original Pavol Dobšinský collection of Slovak fairy tales showed that there are certain stylistic features (pronouns, particles, evaluative and expressive attributes, tautological expressions) that are typical of folk narrative and that capture the authenticity of the oral tradition in direct contact with the listeners. ${ }^{25}$ Specific word order might be - in our opinion - seen as another feature of dialect folk narrative and the original Šariš fairy tales word order simply reflects the oral form of narration that differs from Šariš written discourse.

In the Slovak version of the tales, on the other hand, we respected current word order rules. We admit that this might mean the neutralising of an authentic Šariš sentence and reducing its expressivity for the sake of natural Slovak word order. But presenting Šariš fairy tales in the same edition alongside their Slovak counterparts should enable the reader to observe the original expressive word order of a spoken discourse, characteristic of the colloquiality of the traditional Slovak fairy tales recorded by Dobšinský. ${ }^{26}$

Trying to name the shifts of the word order made in the Slovak version we must revise the principles that govern Slovak word order, namely: (1) theme-

25 J. Dorula, 1990: O jazyku slovenských ludových rozprávok. (Konfrontácia pôvodného textu s jeho modernizovanou úpravou). „Slovenská reč”, vol. 55, no. 3, p. 130.

26 J. Kačala, 1989: Slovenské ludové rozprávky..., p. 108. 
rheme/topic-comment principle; (2) phonetic principle (enclitics, proclitics), and (3) grammatical principle (regarding the order of attributes in a noun phrase).

The "theme-rheme principle" is different in Šariš dialect fairy tales with the semantically crucial part not necessarily stated at the end of the utterance as is the case in Slovak version that follows standard word-order schemes.

- či nohu abo koriň trime fpisku $\rightarrow$ či v papuli drží nohu alebo koreň. ["whether he holds either leg or a root in his mouth"] ${ }^{27}$;

- Ale aňi jedineho dukata $v$ ladze ňit $\rightarrow$ len $v$ lade niet ani jedného dukáta. ["Because there is no ducat in the chest"].

The rhythmical element, which deals with placing of the enclitics and proclitics, also acts differently in a transcript of a dialect form and in contemporary Slovak usage. Here again, not only the dialect itself but also the diction of a spoken utterance has to be taken into account.

- Liška ket vidzela $\rightarrow$ Ked' líška videla ["When the fox saw..."];

- Bo indzej ce všadzi najdu $\rightarrow$ lebo všade inde ta nájdu ["Because they will find you everywhere else"].

The order of the clauses in a complex sentence is also different:

- bosoroša ňetreba strilac, al’e tak, jak mu patri, žebi zahinul $\rightarrow$ bosoráka netreba zastrelit, ale nech zahynie tak, ako si zaslúži. ["Because they should not shoot the wizard but rather let him die the way he deserves"].

(B) Changes on a syntactic level in Slovak fairy tales include reformulation, which is a means of dealing with differences in prepositional phrases between Šariš and Slovak:

- Jeho gazdiňka śe f kohucikovi cešila, že ma prekrasni hlas $\rightarrow$ Jeho gazdinka sa tešila, že kohútik má prekrásny hlas... [“A housewife was excited that her cock had a beautiful voice"].

(C) There are also morpho-syntactic changes in the valency of the verb from impersonal construction in Šariš to intransitive verb in Slovak:

- lem śe mi chorej bidnej zdrimlo $\rightarrow$ to som si len ja chorá-biedna zdriemla. ["Me sick and poor one have just had a nap"].

The aforementioned differences in valency might bring about the change of the accompanying pronoun (personal $\rightarrow$ reflexive):

- Ona mu na chripce dudrala $\rightarrow$ Ona si na jeho chrbte mrmlala. ["She was just murmuring on his back"].

27 We provide the reader with the English translation of the original Šariš fairy-tale quotes. 


\section{Lexical Differences - False Friends}

When translating within one language - between its vernacular or territorial variety, on the one hand, and standard variety, on the other - false friends tend to be a rather regular and frequent risk. Those words, usually paronymous in form, are only seemingly similar in meaning, but from the semantic point of view might be significantly different. Table 1 lists a few examples with the actual false friends in bold.

TABLE 1. False friends

\begin{tabular}{|c|c|c|c|}
\hline \multicolumn{2}{|c|}{ Jak bul vilk u Satkovich na veśelu } & $\begin{array}{c}\text { Ako bol vlk u Sadkovcov } \\
\text { na svadbe }\end{array}$ & $\begin{array}{l}\text { How a wolf was at the } \\
\text { Sadkos' wedding }\end{array}$ \\
\hline 1. & $\begin{array}{l}\text { A liška mu f̌se kuśčik } \\
\text { kolača dala, žebi ho } \\
\text { lakomila } \rightarrow\end{array}$ & $\begin{array}{l}\text { A líška mu stále dala kúsok } \\
\text { koláča, aby ho navnadila }\end{array}$ & $\begin{array}{l}\text { ["And the fox gave him } \\
\text { a piece of cake just to } \\
\text { tease him more"] }\end{array}$ \\
\hline 2. & $\begin{array}{l}\text { Jedna } z \text { ňich bula poňižena } \\
\text { a cicha }\end{array}$ & $\begin{array}{l}\text { jedna z nich bola skromná } \\
\text { a tichá }\end{array}$ & $\begin{array}{l}\text { ["one of them was modest } \\
\text { and shy"] }\end{array}$ \\
\hline 3. & Tam mala liška dziru. & Tam mala liška noru. & $\begin{array}{l}\text { ["There the fox had } \\
\text { a hole"] }\end{array}$ \\
\hline 4. & $\begin{array}{l}\text { Uvidzela na chiži poros- } \\
\text { sipovane dukati, vźala } \\
\text { i do ruki jeden, či su, reku, } \\
\text { spravodlìve. } \rightarrow\end{array}$ & $\begin{array}{l}\text { Uvidela v izbe po- } \\
\text { rozhadzované dukáty, } \\
\text { a vzala i jeden do ruky, či } \\
\text { sú, reku, pravé }\end{array}$ & $\begin{array}{l}\text { ["She had spotted ducats } \\
\text { scattered on the floor and } \\
\text { took one to find out if } \\
\text { they were genuine"] }\end{array}$ \\
\hline 5. & $\begin{array}{l}\text { bo u nas doma ňijakej } \\
\text { hadzini ňit } \rightarrow \\
\text { nema žadnu hadzinu } \rightarrow\end{array}$ & $\begin{array}{l}\text { nemáme čo chovat. } \\
\text { nemá žiaden majetok. }\end{array}$ & $\begin{array}{l}\text { ["we don't have any do- } \\
\text { mestic animals to feed"] } \\
\text { ["she doesn't have any } \\
\text { possessions"] }\end{array}$ \\
\hline
\end{tabular}

Commentary:

1. The dialect verb lakomic (dakeho) ("tease sb"), has different semantics as well as valency from the Slovak paronymous verb lakomit' (sa) ("be greedy"), therefore we used the verb navnadit' as an equivalent.

2. The Šariš adjective poňižena ("modest, humble") and Slovak adjective ponižený ("humiliated") differ in meaning, therefore we preferred the equivalent skromný ("humble").

3. Though there is a straight Slovak equivalent diera for the Šariš noun dzira ("a hole"), a fox's habitat is typically called "nora" ("a den").

4. Although there is similarity in form between the Šariš adjective spravodlivi and Slovak adjective spravodlivý, the semantics of the Šariš word is rather closer to a neutral expression pravý. 
5. The collective noun hadzina has an equivalent in Slovak, the noun hydina, ${ }^{28}$ which would be inconsistent in the presented contexts. Therefore, it was replaced by neutral formulations and descriptive phrases in the Slovak translation.

\section{Lexical Differences - Phraseology}

Idiomatic expressions tend to be language-specific and unique and the same is true of dialect phraseology which stresses the importance of finding the equivalent idiom and thus making the translation sound natural. In this intralingual translation we adopted an individual approach to each idiom. With some it felt appropriate to preserve the tonality of the text by respecting the original greeting. The dialect construction Dajbože, kohucik, co ňemame differs from the archaic Slovak greeting Dajbože (štastia)! But to add the authenticity and the colour of expression we preserved the original form in Slovak translation, not the typical archaic Slovak form:

Dajbože, kohucik, co ňemame $\rightarrow$ Dajbože, kohútik, čo nemáme, kamže ideš, kam? ["May God give us, what we don't have - where are you going?"]

On the other hand, there were cases when we used the opposite approach and adapted the construction so that it served as a standard Slovak greeting. Panbuhdaj, kohuciku, dzeže idzě̌, dze? $\rightarrow$ Pánboh daj štastia, kohútik, kamže ideš, kam? ["May God give us happiness, where are you going?"]

\section{Changes of Expressiveness}

Dialect discourse is characterized by greater expressiveness which is due to the fact that

[d]ialects are employed only in a spoken form and most often in a family environment that enables extensive use of expressive constructions. While the expressive words do not enrich naming options of the language, they certainly widen its stylistic capabilities and that is very important for today's dialects as the intimate means of communication. ${ }^{29}$

28 F. Buffa, 2004: Slovník šarišských nárečí. Prešov, Náuka, p. 86.

29 F. Buffa, 2004: Slovník šarišských nárečí.., p. 341. 
Expressive words represent an important part of dialect vocabulary, which is in sharp contrast to the stylistic norms of a written Slovak text.

However, expressiveness present in these Šariš folk narratives may also be a result of the literary genre of fairy tales itself. It is a well-known fact a fairy tale is characterized by rich fantasy and imagery. Moreover, the language of fairy tales contains

not only words that a child is familiar with, but also those less familiar or even unknown. A child is enchanted by the sounds, their rhythm [...] we can't ignore how important it is that this language bath, into which a child is immersed, is abundant. $^{30}$

This, of course, suggests that the vocabulary employed in a fairy tale might be more expressive than a child is used to, and that is certainly true to even a greater extent when dialect comes into play.

One of the expressive Šariš lexemes that was a challenge to translate in the fairy tales was the word dupa ("little bum"). It is widely used in child-oriented discourse and/or in an affectionate way both in dialect and in sub-standard Slovak in eastern Slovakia; however, it is definitely not recognized or understood across Slovakia. As Table 2 illustrates, different equivalents were chosen for its translation (zadok, zadoček, pod chvost). A certain evening out of expressivity and explicitness (constructions pod chvost/spod chvosta - "under the tail," "from under the tail") has to be applied to make the Slovak translation sound more neutral and follow the genre norm of fairy tales in Slovak.

TABLE 2. Expressive lexeme dupa/dupka

\begin{tabular}{|c|c|c|c|}
\hline & Zazračni dzvonček & Zázračný zvonček & [Little Miraculous Bell] $^{31}$ \\
\hline 1. & $\begin{array}{l}\text { - Ta chibal' do dupi, bo } \\
\text { indzej ňit dze. } \\
\text { - Choc i tam, - a skril śe } \\
\text { do dupi kohucikovej. }\end{array}$ & $\begin{array}{l}\text { - Tak azda len pod chvost, } \\
\text { lebo inde niet kam. } \\
\text { - Hoci aj tam, - a tchor } \\
\text { sa skryl kohútikovi pod } \\
\text { chvost. }\end{array}$ & $\begin{array}{l}\text { [So rather under the tail, } \\
\text { because there is no other } \\
\text { suitable place. } \\
\text { - Ok, then, - and the } \\
\text { skunk hid under the } \\
\text { cock's tail.] }\end{array}$ \\
\hline 2. & $\begin{array}{l}\text { Aňi lem kohucikova dupa } \\
\text { tak chitro jich ňemohla } \\
\text { pozbirac. }\end{array}$ & $\begin{array}{l}\text { ani len kohútik ich nemo- } \\
\text { hol napochytre pod chvost } \\
\text { pozberat' }\end{array}$ & $\begin{array}{l}\text { [Not even the cock could } \\
\text { collect them quickly under } \\
\text { its tail.] }\end{array}$ \\
\hline
\end{tabular}

30 J. Heldová, 1985. V řiši obrazotvornosti. Praha, Albatros, p. 172; cf. Radoslav Rusňák, 2008: Moderná rozprávka a jej detská recepcia. Prešov, Prešovská univerzita v Prešove.

31 The English version is a literal translation of the Slovak text. 


\begin{tabular}{|c|c|c|c|}
\hline 3. & $\begin{array}{l}\text { A ket už šicku vodu } \\
\text { vipil, zapchala mu dupu } \\
\text { d'ugovom. }\end{array}$ & $\begin{array}{l}\text { A ked'už vypil všetku vodu, } \\
\text { zapchala mu zadok zátkou. }\end{array}$ & $\begin{array}{l}\text { [And when he had drunk } \\
\text { all the water, the fox } \\
\text { plugged up his bum.] }\end{array}$ \\
\hline 4. & Dupko moja, pij vodičku. & Zadoček môj, pi vodičku. & [Little bum, drink water] \\
\hline 5. & a dupa vidala vodu & $\begin{array}{l}\text { a kohútikovi sa spod chv- } \\
\text { osta vyliala voda. }\end{array}$ & $\begin{array}{l}\text { [And the water poured } \\
\text { out from underneath the } \\
\text { cock's tail.] }\end{array}$ \\
\hline 6. & Dupka pozbirala dukati. & $\begin{array}{l}\text { Kohútik zadočkom pozber- } \\
\text { al dukáty. }\end{array}$ & $\begin{array}{l}\text { [And the cock collected } \\
\text { ducats with his little } \\
\text { bum.] }\end{array}$ \\
\hline
\end{tabular}

The word dupa also occurs in the Šariš title of the fairy tale Zazračna dupa with the subtitle Kohucik vislužil, kurka ňe (Miraculous Bum - A Cock Earned Something, a Hen did not). In Slovak translation we preferred to use the less controversial Slovak fairy tale subtitle only: Kohútiks vyslúžkou, sliepočka bez.

\section{Expressing Violence}

Among the facets of expressiveness is depiction of violence. But "for a pre-school child violence and cruelty in fairy tales is acceptable, because it is in accordance with their understanding of death that a pre-school child does not perceive as final." ${ }^{32}$ It is also worth mentioning here again the analogy with the Dobšinskýs Slovak folk tales and their contemporary edition, which had the tendency to moderate drastic, cruel scenes and merciless punishments typically present in prototypical folk tales. $^{33}$

In our translation process we observed that Šariš fairy tales expose violence more openly than Slovak stylistic fairy tale norms would allow. The ratio of expressive words used by male vs. female narrators is different. ${ }^{34}$ While female narrators clearly preferred more diminutive forms (stories Chto mudri - ňeglupi and Zazračni dzvonček), male narrators had no trouble expressing rather

32 J. Šeligová, [online]: 2010. Rozprávka a jej význam v súčasnej rodine. [Diploma thesis] Praha: Univerzita Karlova, p. 22; https://dspace.cuni.cz/bitstream/han dle/20.500.11956/33754/DPTX_2010_1__0_120793_0_100501.pdf? sequence=1 (13.09.2019).

33 J. Dorula, 1990: O jazyku slovenských ludových rozprávok. (Konfrontácia pôvodného textu s jeho modernizovanou úpravou)..., p. 135.

34 The name of the narrator was recorded together with the fairy tale. 
cruel concepts (stories: Zazračna dupa - kohucik vislužil, kurka ňe; Sprosti vilk, 126 Jak bul vilk u Satkovich na veśelu). Table 3 illustrates the openness with which dialect stories cover the issue of violence.

TABLE 3. Expression of violence

\begin{tabular}{|c|c|c|}
\hline & & Stupid Wolf \\
\hline $\begin{array}{l}\text { F tim vil'ka dachto šust- } \\
\text { nul - a to bul juhas, bo śe } \\
\text { od ofcoch pripatral, jak vilk } \\
\text { na prikope śpi. } \\
\text { - Ta lačneho a slabeho me } \\
\text { chceš zabic? Počkaj, dokel'se } \\
\text { mi moc navraci, - zah- } \\
\text { varal vilk. } \\
\text { Ale juhas ňečekal, lem bil } \\
\text { a bil, dokel' vilka ňedobil... }\end{array}$ & $\begin{array}{l}\text { V tom vlka ktosi oblial - } \\
\text { a to bol valach, čo sa } \\
\text { prizeral od oviec, ako vlk na } \\
\text { priekope spí. } \\
\text { - Vari ma hladného } \\
\text { a slabého chceš zabit? Poč- } \\
\text { kaj, kým sa mi nenavráti } \\
\text { sila, - zahováral vlk. } \\
\text { Ale valach nečakal, len bil } \\
\text { a bil, kým vlka nedobil... }\end{array}$ & $\begin{array}{l}\text { [Then somebody poured water } \\
\text { over the wolf - and it was the } \\
\text { shepherd who was watching } \\
\text { the wolf sleeping in the ditch. } \\
\text { - Do you want to kill me hun- } \\
\text { gry and weak? Wait until I get } \\
\text { strong again, - said the wolf. } \\
\text { But the shepherd did not wait, } \\
\text { he just kept on beating until } \\
\text { he finished the wolf off.] }\end{array}$ \\
\hline $\begin{array}{l}\text { Ket gazdiňa uvidzela plani } \\
\text { groš, tak śe nazloscila, že } \\
\text { schvacila kuru do jednej } \\
\text { ruki a z druhu jej hlavu } \\
\text { otkrucila. }\end{array}$ & $\begin{array}{l}\text { Ked' gazdiná uvidela planý } \\
\text { groš, tak sa nazlostila, že } \\
\text { schytila sliepku do jednej } \\
\text { ruky a druhou rukou jej } \\
\text { odkrútila hlavu. }\end{array}$ & $\begin{array}{l}\text { [When an old lady spotted } \\
\text { a false ducat, she got so angry } \\
\text { that she grabbed the hen with } \\
\text { one hand and with the other } \\
\text { she twisted off its head.] }\end{array}$ \\
\hline
\end{tabular}

\section{Conclusion}

In the present paper we hoped to show that even dialect as a territorial variety of a single language is an autonomous form that features unique nominal processes that do not necessarily have direct counterparts in the standard form of the language. A dialect might be peripheral in its impact within the context of the whole language territory, but it should certainly not be perceived as marginal. Through our translation analysis we wanted to point out that its specific features make it an unparalleled reflection of extra-linguistic reality that is worthy of preservation. We strongly believe that " $\mathrm{t}]$ he way we speak has a great impact on our relations and on our culture, therefore, it has consequences on a person's life later on." ${ }^{35}$ That is why we should provide the next generations with enough inputs to develop their competence in dialects, both in spoken and written form.

35 H. Giles, N. Coupland, 1991: Language: Context and Consequences. Pacific Grow, Brooks/Cole; cf. A. Arzu, T. Issa, 2014: An Effect on Cultural Identity: Dialect. „Procedia - Social and Behavioral Sciences" 143, p. 562. 


\section{Literature}

Abley M., 2003: Spoken Here. Travels among Threatened Languages. London, Heinemann.

Arzu A., Issa T., 2014: An Effect on Cultural Identity: Dialect. „Procedia - Social and Behavioral Sciences" 143, pp. 555-562.

Barker Ch., 2006: Slovník kulturálních studií. Praha, Portál.

Beel D. et al., 2017: Cultural Resilience: The Production of Rural Community Heritage, Digital Archives and the Role of Volunteers. „Journal of Rural Studies” 54, pp. 459-468.

Buffa F. 1969: Polstoročie výskumu slovenských nárečí. „Slovenská reč”, vol. 34, no. 1, pp. 14-24.

Buffa F., 2004: Slovník šarišských nárečí. Prešov, Náuka.

Casanova P., 1999: La Republique mondiale des lettres. Paris, Seuil.

Cronin M., 2006: Translation and Identity. Oxford-New York, Routledge.

Dorula J.,1990: O jazyku slovenských ludových rozprávok. (Konfrontácia pôvodného textu s jeho modernizovanou úpravou). „Slovenská reč”, vol. 55, no. 3, pp. 129-146.

Heldová J., 1985: V řísi obrazotvornosti. Praha, Albatros.

Giles H., Coupland N., 1991: Language: Context and Consequences. Pacific Grow: Brooks/Cole.

Kačala J., 1989: Slovenské ludové rozprávky a ich súčasné úpravy. „Kultúra slova”, vol. 23, no. 4, pp. 97-110.

Paasi A., 2011: The Region, Identity, and Power. „Procedia. Social and Behavioral Sciences" 14, pp. 9-16.

Paulíny E., 1963: Fonologický vývin slovenčiny. Vydavatel'stvo Slovenskej akadémie vied.

Rusňák R. 2008: Moderná rozprávka a jej detská recepcia. Prešov, Prešovská univerzita v Prešove.

Šeligová J., 2010 [online]: Rozprávka a jej význam v súčasnej rodine. https://dspace .cuni.cz/bitstream/handle/20.500.11956/33754/DPTX_2010_1__0_1207 93_0_100501.pdf?sequence=1 (13.09.2019). 


\title{
Miroslava Gavurová \\ Periféria v rámci jedného jazyka \\ Výzvy prekladu nárečových rozprávok do spisovnej slovenčiny
}

RESUMÉ | Štúdia sa zameriava na prekladatel’ské výzvy intralingválneho prevodu medzi periférnou varietou - dialektom - a spisovnou slovenčinou. Materiálom na preklad i prekladovú analýzu boli unikátne šarišské rozprávky, zachované v obci Fintice, publikované nedávno v šarišsko-slovenskej edícii pod názvom Zazračni dzvonček - Zázračný zvonček (FACE 2018). V prvej časti sa autorka sústreduje na periférne aspekty analyzovaného textu a zdôrazňuje dôležitost̉ zachovania takýchto zabudnutých literárnych prejavov pre identitu komunity a pre zachovanie kultúrneho dedičstva komunity. Druhá čast štúdie pozostáva $\mathrm{z}$ translatologickej analýzy, ktorá pomenúva rozdiely medzi dvoma varietami, ktoré sa objavujú najmä na morfo-syntaktickej a lexikálnej rovine, ako aj v stupni expresivity výrazu. Pomenované špecifiká robia z periférneho nárečového textu jedinečný odraz mimojazykovej skutočnosti, ktorý sa oplatí zachovat.

KLÚČOVÉ SLOVÁ | intralingválny prevod, dialekt, rozprávka, periféria, identita komunity, kultúrne dedičstvo komunity

\author{
Miroslava Gavurová \\ Peryferie w obrębie jednego języka: \\ wyzwania tłumaczenia baśni napisanych w dialekcie \\ na standardowy język słowacki
}

STRESZCZENIE | W artykule opisano wyzwania tłumaczenia wewnątrzjęzykowego z dialektu peryferyjnego na urzędowy, standardowy język słowacki - na przykładzie tłumaczenia baśni z regionu Szarysz, zachowanych w wiosce Fintice. Baśnie te, zatytułowane Zazračni dzvonček - Zázračný zvonček, ukazały się nakładem wydawnictwa FACE w 2018 roku w formie dwujęzycznej (z tłumaczeniem na język słowacki). W pierwszej części artykułu wyszczególniono peryferyjne aspekty analizowanego tekstu i podkreślono potrzebę wydawania zapomnianych utworów literackich dla podtrzymania tożsamości społeczności i jej dziedzictwa kulturowego. W drugiej części artykułu zawarto analizę przekładu, wskazując różnice między oryginałem a translacją na poziomie morfosyntaktycznym i leksykalnym oraz różnice w stopniu ekspresji.

SŁOWA KLUCZOWE | tłumaczenie wewnątrzjęzykowe, dialekt, baśnie, peryferie, tożsamość społeczności, dziedzictwo kulturowe społeczności

MIROSLAVA GAVUROVÁ | PhD., born in 1976 in Prešov, Slovakia, is Assistant Professor at the Institute of British and American Studies at the University of Prešov. Her research concentrated on the lexicology and, more specifically, abbreviatology the result of which was the monograph An Abbreviation as a Lexeme (2013). Recently her research interest has shifted towards the issue of identity as reflected in the specifics of peripheral forms of language, namely 
dialects. She translates from English to Slovak; her book translations include the series of Paddington Bear (Michael Bond), The Frog and Toad (Arnold Lobel) and other translations of fiction. 